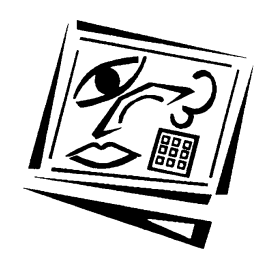

\title{
Media presentation mode, English listening comprehension and cognitive load in ubiquitous learning environments: Modality effect or redundancy effect?
}

\author{
Chi-Cheng Chang, Hao Lei and Ju-Shih Tseng \\ National Taiwan Normal University
}

\begin{abstract}
Although ubiquitous learning enhances students' access to learning materials, it is crucial to find out which media presentation modes produce the best results for English listening comprehension. The present study examined the effect of media presentation mode (sound and text versus sound) on English listening comprehension and cognitive load. Participants were 162 students majoring in Applied Foreign Language at a university in Taiwan. The students were randomly assigned to either single mode (sound) or double mode (sound and text). The research questions are (a) whether students learning with double mode outperformed students learning with single mode in listening comprehension; and (b) whether students learning with double mode encountered less cognitive load than students learning with single mode. If the answers to these questions are affirmative, then the modality effect occurs and the redundancy effect does not occur. The results demonstrated that (a) text significantly enhanced English listening comprehension and lowered cognitive load; (b) students with higher English listening comprehension experienced lower cognitive load, and vice versa; (c) text added no benefit to schema construction in long term memory; and (d) complex media presentations were not necessarily helpful to learning. Results (a) and (b) confirmed that the modality effect occurred, and the redundancy effect did not occur in the present study.
\end{abstract}

\section{Introduction}

\section{Background}

Listening comprehension is difficult for foreign language learners because it is a continuous process that requires learners to understand messages while listening to them and sometimes can lead to a heavy cognitive load. In order to minimise listening barriers, various media presentation modes and ubiquitous learning activities should be implemented for teaching and learning because they are convenient and can enhance students' learning motivation and learning performance (Liu \& Chu, 2010). "Ubiquitous learning" involves a context-aware environment that users engage in with some mobile devices (Chang, Sheu \& Chan, 2003; Li, Zheng, Ogata \& Yano, 2005; Tan, Liu \& Chang, 2007). Yang (2006) established a context-aware learning system with the support of multimedia for ubiquitous learning, so students were able to get the information they needed anytime and anywhere. Hence, students learning in an authentic situation may have better English listening comprehension due to an enhanced sensory stimulation. 
The impacts of different media presentation modes on learning remain inconclusive. According to the working memory model proposed by Baddeley (2000), working memory can simultaneously receive information from different channels, such as auditory and visual. Thus, when the efficiency of the working memory is improved, learning performance will also be enhanced. However, Kalyuga, Chandler and Sweller (2000) suggested that some multimedia learning software can lead to cognitive overload, which affects learning performance negatively. Sweller (2005) also argued that unnecessary or repeated multimedia messages can result in a redundancy effect, which negatively affects learning performance.

Multimedia helps learners learn, but different media presentation modes affect learners' cognitive load differently (Moreno, 2002; Mayer \& Moreno, 2003; Plass, Chun, Mayer \& Leutner, 2003). Sweller (2007) mentioned that the purpose of instructional design is to assist learners to store information in long term memory. This implies that the way teaching materials presented to learners is a key element in instructional design. Attention to cognitive load is a critical concern for instructional designers when designing multimedia teaching materials, because unnecessary multimedia messages may worsen learning performance by increasing working memory load and interrupting information processing (Sweller, 2007).

Multimedia instructional systems have been widely applied in teaching and learning, but the media presentation mode that is best for English listening comprehension remains uncertain, and whether unnecessary information led to cognitive overload for learners also remains inconclusive. According to the studies done by Jones and Plass (2002) and Diao, Chandler and Sweller (2007), students learning with double mode (sound and text) outperformed students learning with single mode (sound) and had lower cognitive load. Studies related to foreign language learning and cognitive load are mostly about digital learning environments. Hence, the present study examined the effect of media presentation mode on listening comprehension in a ubiquitous learning environment to see if there were any differences from the studies on digital learning environments. Which media presentation mode can efficiently help learners store information in long term memory is another issue to be further examined.

\section{Research purpose and questions}

The present study aimed to examine the effect of media presentation mode (single mode: sound; double mode: sound and text) on English listening comprehension and cognitive load in a ubiquitous learning environment. The research questions include:

1. Are there any significant differences in English listening comprehension between two media presentation modes?

2. Are there any significant differences in cognitive load between two media presentation modes?

3. Are there any significant correlations between English listening comprehension and cognitive load?

4. Are there any significant differences in extended English listening comprehension between two media presentation modes?

5. Are there any significant differences in extended cognitive load between two media presentation modes?

6. Are there any significant correlations between extended English listening comprehension and extended cognitive load? 


\section{Literature review}

\section{Listening in foreign language learning}

Although listening has played a crucial role in foreign language learning, it has often been neglected by instructors (Osada, 2004). Nevertheless, listening examination has been included in most English proficiency examinations, such as TOFEL, TOEIC and GEPT, which implies the importance of listening. Listening comprehension is a difficult task for foreign language learners to master due to the interference of first language and the limitation of listening time (Teng, 2006). Thus, instructors must design teaching materials and learning activities appropriately for learners to learn efficiently. Teaching materials can be delivered through the support of multimedia, with the intention that sound can be presented to learners with text, image or video (Tabbers, Martens \& Van Merriënboer, 2004). Therefore, learners can learn not only by single mode (sound) but also other modes with the support of multimedia, which will stregthen their learning motivation.

\section{Ubiquitous learning}

Elements of ubiquitous learning

Ubiquitous learning refers to a context-aware learning environment that learners engage in with a mobile device and the Internet (Chang, Sheu \& Chan, 2003; Li, Zheng, Ogata \& Yano, 2005; Tan, Liu \& Chang, 2007). Chang (2003) mentioned three main fundamental elements for ubiquitous learning, including (a) a mobile device, such as a PDA (personal digital assistant), web pad or tablet PC, which is small, light, portable and customised with a wireless facility; (b) communication facility, such as mobility server and Global Positioning System (GPS), which enables learners to obtain materials and communicate with one another; and (c) learning activity, which should be implemented appropriately in the instruction and makes learning become meaningful.

\section{Ubiquitous learning and foreign language learning in listening}

Ubiquitous learning enables learners to learn in their daily life and helps them to overcome limitations of time and space. Learners who study a foreign language with mobile devices will be able to experience learning from an authentic situation and have their learning performance enhanced (Nash, 2007), as multiple sense stimuli may be more helpful to learners in absorbing knowledge. So far, ubiquitous learning has been implemented in many types of learning, such as museum tours, natural science learning and language learning, etc (Chen \& Chung, 2008; Chiou, Tseng, Hwang \& Heller, 2010; Tan et al., 2007). Well-designed ubiquitous learning can enhance English learners' motivation and learning performance (Chen \& Chung, 2008; Liu \& Chu, 2010). Since learners have different educational backgrounds and learning preferences, it is better for learners to learn at their own pace and obtain information they need at any time (Yang \& Lin, 2010).

\section{Cognitive load theory}

Sources of cognitive load

Cognitive load is a load upon working memory produced when a particular task is processed by one's cognitive system (Sweller et al., 1998). Sweller et al. (1998) proposed four basic hypotheses toward cognitive architecture based on the cognitive load theory, including: (a) capacity of working memory is limited; (b) capacity of long term 
memory is unlimited; (c) knowledge is stored as schema in long term memory; and (d) automation is an important process for schema construction. A well-designed media presentation mode will help learners build up schema for storing the obtained information in the long term memory. Moreover, a learning activity with an appropriate media presentation mode can also facilitate schema automation and construction, so learners' cognitive load can be lowered and learning performance can be enhanced.

There are three types of cognitive load (Pawley, Ayres, Cooper \& Sweller, 2005; Paas, Renkl \& Sweller, 2003), which are:

1. Intrinsic cognitive load

The higher the correlation between the nature of the material being learned and the expertise of the learners, the lower the load in working memory because learners will be able to retrieve relevant information from long term memory. On the other hand, the lower the correlation between the nature of the material being learned and the expertise of the learners, the higher the load in working memory because there is no related schema in long term memory and learners are required to process more in working memory. Therefore, intrinsic cognitive load cannot be lowered easily by instructional design.

2. Extraneous cognitive load

Extraneous cognitive load can be affected by presentation modes of teaching materials. Thus, extraneous cognitive load can be lowered by instructional design, which is also a point for the present study.

3. Germane cognitive load

Germane cognitive load can be affected by instructional design and is thought of as a facilitator of learning performance, not an interrupter. Instructors can facilitate learners' learning motivation by learning activities, which make learners become more concentrated on learning and help them to construct schema.

Since it has been difficult to lower one's intrinsic cognitive load by instructional design and the impact of germane cognitive load will be small (because learners were participating in the same learning activity), only extraneous cognitive load has been examined in the present study.

\section{Modality effect and redundancy effect}

Modality effect is defined as an effect in which learners perform well when they receive information from various channels, such as visual and auditory (Sweller, 2005). A number of researchers have confirmed the modality effect (Debuse, Hede \& Lawley, 2009; Diao et al., 2007; Jones \& Plass, 2002; Low \& Sweller, 2005; Moreno \& Mayer, 2002; Plass et al., 2003; Tabbers, Martens \& Van Merriënboer, 2004). On the other hand, a redundancy effect happens when too much useless information is added to learners' working memory, which leads to high extraneous cognitive load. Again, numerous researchers have confirmed the modality effect (Debuse, Hede \& Lawley, 2009; Jamet \& Bohec, 2007; Kalyuga, Chandler \& Sweller, 2000; Mayer, Heiser \& Lonn, 2001; Mayer \& Moreno, 2003; Moreno \& Mayer, 2002; Sakar \& Ercetin, 2005). Consequently, the media presentation modes in the present study were designed based on the ideas of the modality effect and the redundancy effect. The teaching materials for the single mode group and the double mode group were the same. The only difference between both 
groups was that participants in the single mode group learned with sound only and the double mode group learned with sound and text.

Cognitive load and listening in foreign language learning

From the perspective of the modality effect, double mode, including visual and auditory, will be expected to enhance learning performance. A study done by Markham (1999) revealed that foreign language learners who learned with double mode had better listening comprehension. However, from the perspective of the redundancy effect, double mode will not be beneficial to learning. Research by Diao et al. (2007) demonstrated that text was not helpful to listening comprehension. Hence, the results from different studies on listening in a foreign language have been inconsistent.

A study on French learning, with university students as participants, by Jones and Plass (2002) supported the proposition that simultaneous visual and auditory presentations can cause the modality effect, which lowers extraneous cognitive load and enhances learning performance. Another study about English learning, also with university students as participants, by Daio et al. (2007) revealed that double modes, such as sound and complete paragraph, and sound and caption, were better for enhancing listening comprehension and lowering cognitive load than sound-only presentation mode. Both studies showed that double mode tends to cause a modality effect.

However, double mode will also cause a redundancy effect. Diao and Sweller (2007) conducted a study with university students which demonstrated that text-only presentation mode was better than synchronised sound and text presentation mode, for both performance and cognitive load. This result supported the proposition that the redundancy effect occurs when sound is presented simultaneously with text, which is not beneficial to learning. However, this study did not take learners' prior knowledge into account. A Chinese learning study, with high school students as participants, done by Chung (2008) revealed that students with high prior knowledge performed better in memory tests and encountered low cognitive load when visual and auditory were presented simultaneously, which led to the modality effect. On the other hand, learners with low prior knowledge performed better in memory tests and encountered lower cognitive load when visual was presented only, which caused the redundancy effect. This study also revealed that learners' prior knowledge could be a main factor that caused the modality effect and the redundancy effect.

In sum, the studies mentioned above all showed that learners who encountered high cognitive load attained a lower learning performance. Therefore, decreasing extraneous cognitive load for learners is an important goal for instructional designers (Sweller et al., 1998). Learners' proficiency in English listening was considered as an extraneous variable in the present study, as since differences in proficiencies could affect the findings.

\section{Research method}

\section{Participants}

Participants were 162 university students in Taiwan, aged from 18 to 23, majoring in Applied Foreign Language with the same instructor. These participants were assigned randomly to the single mode (82 students) or double mode (80 students) group. The 
participants had similar academic proficiency because all students had been assigned to the university based on their scores obtained from the Joint College Entrance Examination. Before the experiment started, all the participants had been familiarised with the PDA (Hewlett Packard $P A Q 112$ Classic, 3.5 inch screen).

The ubiquitous learning activity in the present study was held at the Taipei Zoo. The Taipei Zoo is one of the main Natural Science Education centres in Taiwan, where people can acquire knowledge about animals and nature. Since the topic of the learning activity was related to animals, it was more appropriate for learners to learn in the zoo. Learning in the zoo enabled learners to experience an experiential learning. With the support of PDA, teaching efficiency and learning motivation are enhanced, which can be a contribution to education. The possible career opportunities for students majoring in Applied Foreign Language are tour guides, who can speak more than one second language, and foreign language teachers. So, the experiment in the present study provided an opportunity for the participants to visit a potential future workplace.

\section{Research design}

The independent variable in the present study was media presentation mode, being single mode (sound only) and double mode (sound and text). The dependent variables were learners' English listening comprehension and cognitive load. There were two tests in the present study. The first test, for examining the participants' listening comprehension, was given immediately after concluding the ubiquitous learning activity. The second test was given to the participants one week after the learning activity was over, to assess their extended listening comprehension. The covariate variable was English listening proficiency, measured by the General English Proficiency Test (GEPT).

As shown in Table 1, participants in both groups took the GEPT as the pretest. In the ubiquitous learning activity, participants in the single mode group learned with soundonly materials whilst the double mode group learned with sound and text materials. In the extended learning activity, both groups learned with sound-only extended materials. After the learning activity, both groups took English listening tests and cognitive load questionnaires as the post-test.

Table 1: Research design (ubiquitous learning)

\begin{tabular}{|c|c|c|c|c|}
\hline Group & $\mathrm{N}$ & Pretest & Experiment & Post-test \\
\hline Single & 82 & \multirow{2}{*}{$\begin{array}{c}\text { General English } \\
\text { Proficiency Test } \\
\text { (GEPT) }\end{array}$} & $\begin{array}{c}\text { Sound only } \\
\text { English listening material }\end{array}$ & \multirow{2}{*}{$\begin{array}{l}\text { English listening tes } \\
\text { Cognitive load }\end{array}$} \\
\hline Double & 80 & & $\begin{array}{l}\text { Concurrently sound and text } \\
\text { English listening material }\end{array}$ & \\
\hline
\end{tabular}

Table 2: Research design (extended listening)

\begin{tabular}{|c|c|c|c|c|}
\hline Group & $\mathrm{N}$ & Pretest & Experiment & Post-test \\
\cline { 1 - 2 } Single & 82 & $\begin{array}{c}\text { General English } \\
\text { Proficiency Test } \\
\text { (GEPT) }\end{array}$ & $\begin{array}{c}\text { Sound only } \\
\text { English listening material }\end{array}$ & $\begin{array}{c}\text { English listening test } \\
\text { Cognitive load }\end{array}$ \\
\hline
\end{tabular}


After the data collection, two-way multivariate analysis of covariance (MANCOVA) was conducted to examine the differences between the posttest scores obtained by the two groups, and the covariate variable was based on the score of the pretest. To examine the relationships between listening comprehension and cognitive load, a Pearson correlation was performed. The research framework is shown in Figure 1.

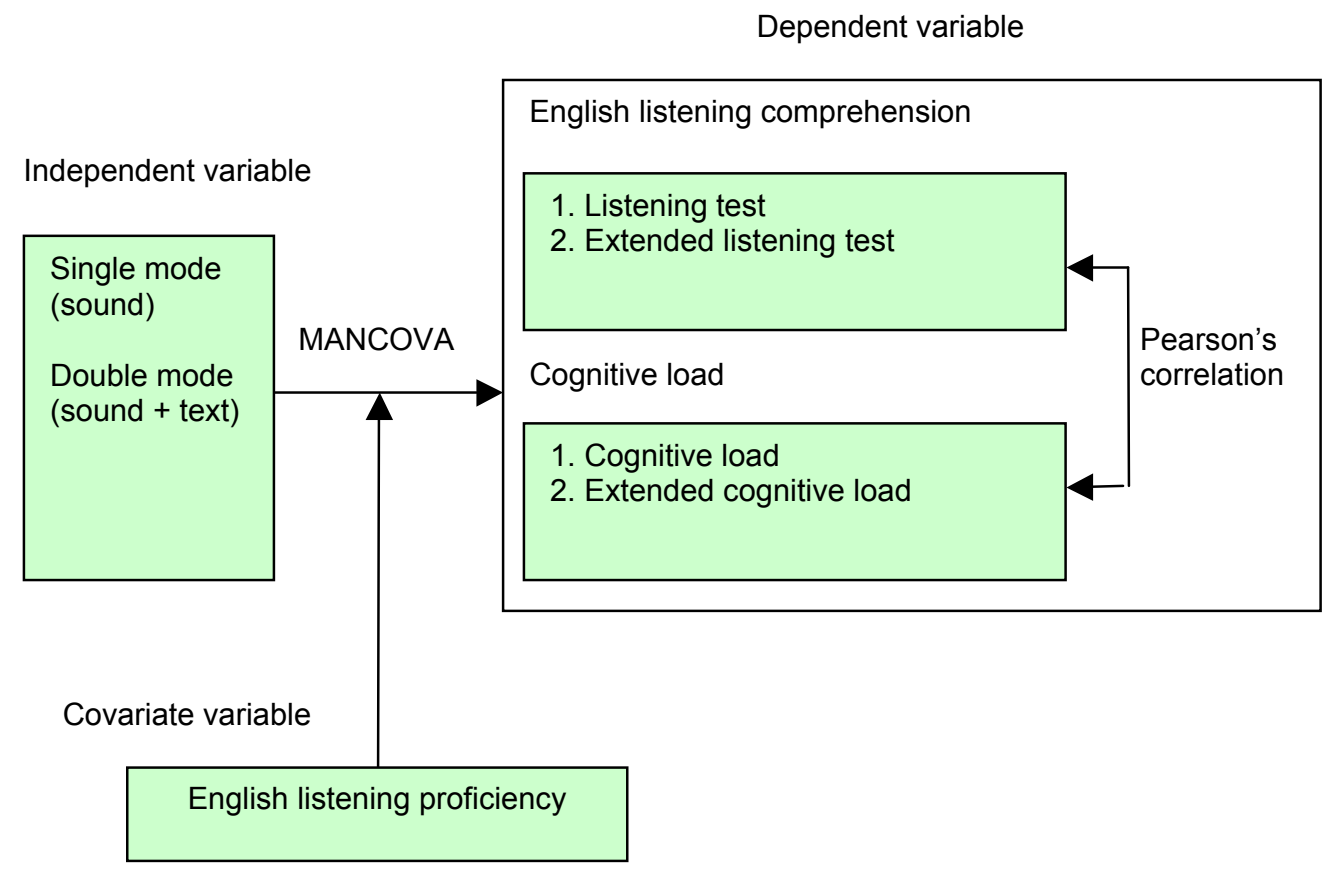

Figure 1: Research framework

\section{Procedure}

There were four stages in the experiment including pretest (first week), training (second week), intervention and post-test (third week), and extended learning and extended post-test (fourth week), as shown in Table 3 and Figure 2.

\section{Instrument}

English listening proficiency test

The General English Proficiency Test (GEPT) was utilised in the present study to determine students' proficiency in English listening, as the GEPT is a graduation requirement for the students majoring in Applied Foreign Language. There were 20 multiple choice questions given by sound speech in the test. Each question was worth five points, and the total possible score for the test was 100. 
Table 3: Experimental procedure

\begin{tabular}{|c|c|}
\hline Stage & Description \\
\hline $\begin{array}{l}\text { Pretest } \\
\text { (First week) }\end{array}$ & $\begin{array}{l}\text { The pretest was administrated during the class ( } 1.5 \text { hours): } \\
\text { 1. The instruction for the test was given by the instructor ( } 0.5 \text { hour). } \\
\text { 2. Students took listening test from GEPT ( } 1 \text { hour). }\end{array}$ \\
\hline $\begin{array}{l}\text { Training } \\
\text { (Second week) }\end{array}$ & $\begin{array}{l}\text { The training was provided during the class ( } 3 \text { hours): } \\
\text { 1. Introduction to ubiquitous learning, PDA (HP } i P A Q 112 \text { Classic, } 3.5 \text { inch } \\
\text { screen) and GPS, including practical experience on using PDA and GPS. } \\
\text { 2. Instructor provided key words that would be included in the material. }\end{array}$ \\
\hline $\begin{array}{l}\text { Intervention and } \\
\text { post-test } \\
\text { (Third week) }\end{array}$ & $\begin{array}{l}\text { Ubiquitous learning and test in the zoo ( } 4 \text { hours): } \\
\text { 1. Students were randomly assigned into two groups with either single or } \\
\text { double mode material. } \\
\text { 2. Students had their PDA connected with GPS. } \\
\text { 3. The system asked students to enter their student ID. } \\
\text { 4. Exploration of animals would be displayed on the screen. Students could } \\
\text { see the map of Africa area in the zoo and their current location. Each animal } \\
\text { was marked on the map and students could decide the listening order by } \\
\text { their preferences. The system guided students to the target by GPS. } \\
\text { 5. When students arrived in the observed area, the system would display its } \\
\text { material automatically by GPS and ask students if they wanted to start the } \\
\text { listening or not. } \\
\text { 6. Students were presented to English listening material by clicking on the } \\
\text { button "Play". } \\
\text { 7. After the speech sound played, students needed to click on the button } \\
\text { "Next Page" for the test page. } \\
\text { 8. After taking the test, students would then continue to the next animal with } \\
\text { the steps mentioned above. } \\
\text { 9. Students were required to fill in the cognitive load rating scale. }\end{array}$ \\
\hline $\begin{array}{l}\text { Extended learn- } \\
\text { ing and extended } \\
\text { post-test } \\
\text { (Fourth week) }\end{array}$ & $\begin{array}{l}\text { Extended listening and test during the class ( } 2 \text { hours) } \\
\text { 1. Students participating in the extended listening activity ( } 1 \text { hour). } \\
\text { 2. Students participating in the extended listening test ( } 0.5 \text { hour). } \\
\text { 3. Students were required to fill in the cognitive load rating scale ( } 0.5 \text { hour). }\end{array}$ \\
\hline
\end{tabular}

\section{English listening material and test}

1. The ubiquitous learning activity and test

A total of four animals, including elephant, lion, monkey and giraffe, were chosen from the Africa area in the Taipei Zoo. Each animal was described by a passage, so there were a total of four passages in the test. The English listening training system was developed by the research team in the present study. The content of the teaching material and the test were adapted from the website of National Geographic (http: / / animals.nationalgeographic.com/animals / ) and San Diego Zoo (http: / / www.sandiegozoo.org/animalbytes/), as shown in Figures 3 and 4. The spoken time for each passage, with length from 180 to 220 words, was about three minutes. There were five multiple-choice questions for each passage, which required students to answer (without time restriction) after listening to each passage. There were 20 questions in the test and one point for each question.

\section{a. Item analysis}

Criterion of internal consistency was adopted by using $t$-test to compare the differences between high scores (top 27\%) and low scores (last 27\%), and a Pearson correlation was performed to examine the relationship between each question and the test, as shown in Appendix 1. The analysis revealed a significant result on critical ratio and item-total correlation. Six out of 20 questions were deleted from the test, so that item internal consistency could be acceptable. 


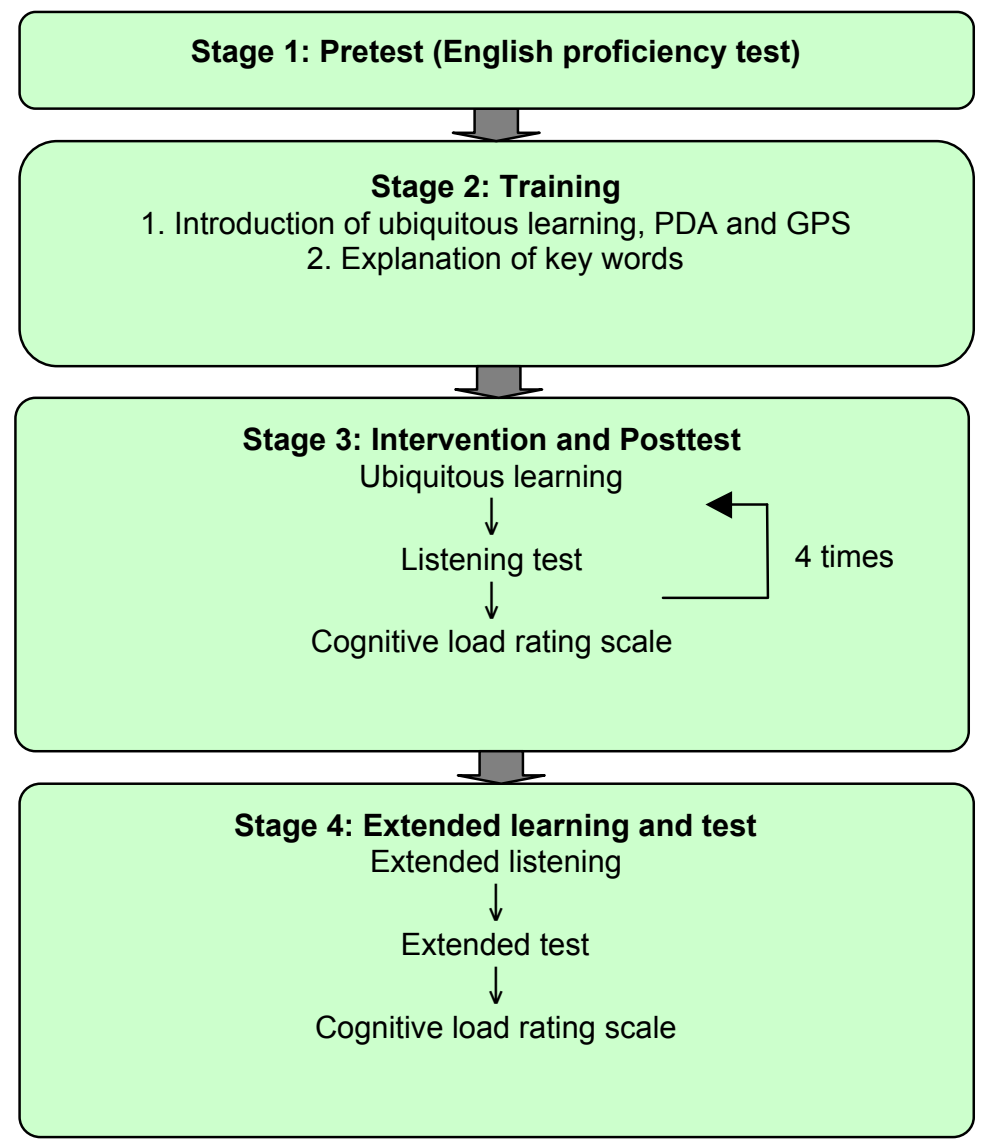

Figure 2: Research procedure

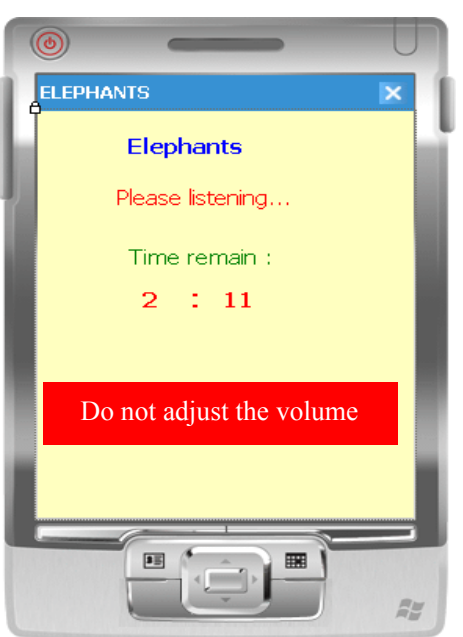

Figure 3: PDA screen of single mode

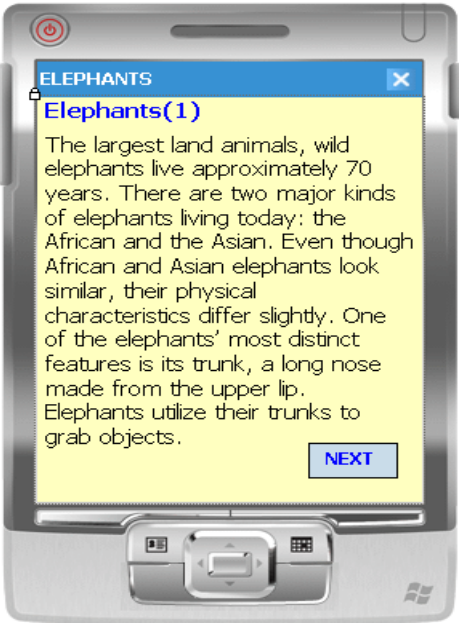

Figure 4: PDA screen of double mode 
b. Difficulty and discrimination analysis

The calculating formula for difficulty index was $\left(\mathrm{P}_{\mathrm{H}}+\mathrm{P}_{\mathrm{L}}\right) / 2$ and discrimination was $\mathrm{P}_{\mathrm{H}}-\mathrm{P}_{\mathrm{L}} \cdot \mathrm{P}_{\mathrm{H}}$ represented students in the top $27 \%$, whereas $\mathrm{P}_{\mathrm{L}}$ represented students in the last $27 \%$. The overall difficulty index for the test was 0.523 and the overall discrimination index was 0.327 , which were acceptable, as provided by Appendix 1.

2. The extended learning activity and extended test

The extended listening test is not the same as the first test mentioned above. But, the vocabularies for the extended material and extended test were chosen from the first test. The purpose of the extended learning material was simply to remind the students of the vocabularies in the first test. The extended test was to examine learners' schema construction in long term memory, so the extended test was administrated only through speech sound. There was one passage, with length of 220 words, followed by five multiple choice questions in the test. The total score for the extended test was five points.

a. Item analysis

The method for the item analysis was same as the test mentioned above, as shown in Appendix 2, and no question was deleted.

b. Difficulty and discrimination analysis

The overall difficulty index for the extended test was 0.418 and the overall

discrimination index was 0.519, which were acceptable, as shown in Appendix 2.

3. Cognitive load rating scale

The cognitive load rating scale by Yeung et al. (2000) was adopted in the present study, as shown in Table 4. The rating scale included four aspects, which were difficulty, incompetence, negative affect and lack of effort. The reliability for each aspect was ranged from 0.78 to 0.93 , which was acceptable. The factor loadings for all the items were greater than 0.5 and the four factors accounted for more than $50 \%$ of total explained variance. Therefore, the validity of the rating scale was satisfied. The participants were required to rate themselves on a 5-point Likert-type scale with response options from 1 (strongly agree) to 5 (strongly disagree).

The cognitive load formula proposed by Yeung et al. (2000) is as follows, the higher the score, the higher the estimated cognitive load.

\section{Cognitive load $=\mathbf{D}^{*} \mathbf{I} / \mathbf{A}+\mathbf{D}^{*} \mathrm{I} / \mathrm{E}$}

D = Difficulty; I = Incompetence; $\mathbf{A}$ = Negative affect; $\mathbf{E}$ = Lack of effort

a. Item analysis

The criterion of internal consistency was adopted by using a $t$-test to compare the differences between high scores (top 27\%) and low scores (last 27\%), and a Pearson correlation was performed to examine the relationship between each question and the test. The analysis revealed a significant result on critical ratio and item-total correlation. The item internal consistency of the test was acceptable without deleting any item, as shown in Appendix 3. 
Table 4: Cognitive load rating scale

\begin{tabular}{|c|c|c|}
\hline Aspects & Description & Item \\
\hline \multirow[t]{4}{*}{ Difficulty } & \multirow{4}{*}{$\begin{array}{l}\text { Self-perceived difficulty } \\
\text { toward the task. The higher } \\
\text { the score, the more difficult } \\
\text { the task. }\end{array}$} & 01. I think the material is very easy. ${ }^{*}$ \\
\hline & & 02. I think the material is too difficult. \\
\hline & & 03. I did not face any difficulty when I took the test.* \\
\hline & & 04. I faced difficulty when I took the test. \\
\hline \multirow{4}{*}{$\begin{array}{l}\text { Incomp- } \\
\text { etence }\end{array}$} & \multirow{4}{*}{$\begin{array}{l}\text { Self-perceived incomp- } \\
\text { etence toward the task. The } \\
\text { higher the score, the higher } \\
\text { the level of incompetence. }\end{array}$} & 05. I do not perform well in the lesson. \\
\hline & & 06. I think I get correct for each question. ${ }^{*}$ \\
\hline & & 07. I think I perform well in the lesson. ${ }^{*}$ \\
\hline & & 08. I do not answer questions incorrectly. ${ }^{*}$ \\
\hline \multirow{4}{*}{$\begin{array}{l}\text { Negative } \\
\text { affect }\end{array}$} & \multirow{4}{*}{$\begin{array}{l}\text { Attitude toward the task. } \\
\text { The higher the score, the } \\
\text { higher the motivation. }\end{array}$} & 09. I like the material. ${ }^{*}$ \\
\hline & & 10. I am interested in the material.* \\
\hline & & 11. I hate to do such kind of test again. \\
\hline & & 12. I think it is fine for me to do such kind of test again.* \\
\hline \multirow{4}{*}{$\begin{array}{l}\text { Lack of } \\
\text { effort }\end{array}$} & \multirow{4}{*}{$\begin{array}{l}\text { Lack of effort toward the } \\
\text { task. The higher the score, } \\
\text { the less the effort. }\end{array}$} & 13. I worked hard for the test.* \\
\hline & & 14. I concentrated on the lesson.* \\
\hline & & 15. I did my best with the test.* \\
\hline & & 16. I worked hard for the lesson.* \\
\hline
\end{tabular}

* Negative items

b. Analysis of validity

As shown in Table 5, Bartlett's test of sphericity and Kaiser-Meyer-Olkin measure of sampling adequacy (KMO) were performed at first. The results showed that Bartlett's test of sphericity was significant and KMO was greater than 0.5 , meaning that the correlation matrix was not an identity matrix and the factor model was appropriate for proceeding a factor analysis. A principal components analysis with orthogonal rotation was conducted for the factor analysis. The factor loadings for each item were greater than 0.5 and the validity coefficient was greater than 0.1 , therefore all items did not have to be deleted, as shown in Appendix 5. The eigenvalue of each aspect was greater than 1, so four aspects could be established. The total explained variance was greater than 50\%, implying that the construct validity of the rating scale was good enough.

Table 5: Factor analysis for the cognitive load rating scale

\begin{tabular}{|c|c|c|c|c|}
\hline \multirow{2}{*}{ Aspect } & \multicolumn{2}{|c|}{ Bartlett's test of sphericity } & \multirow{2}{*}{ KMO } & \multirow{2}{*}{$\begin{array}{c}\text { Total variance } \\
\text { explained }\end{array}$} \\
\hline & Chi-square & $\mathrm{P}$ & & \\
\hline Difficulty & 121.036 & 0.000 & 0.748 & $57.343 \%$ \\
\hline Incompetence & 129.890 & 0.000 & 0.693 & $56.175 \%$ \\
\hline Negative affect & 205.013 & 0.000 & 0.793 & $67.066 \%$ \\
\hline Lack of effort & 193.779 & 0.000 & 0.785 & $65.040 \%$ \\
\hline Overall & 902.031 & 0.000 & 0.806 & $65.813 \%$ \\
\hline
\end{tabular}

c. Analysis of reliability

As shown in Table 6, the reliability coefficient of the measures of cognitive load was .814 , as measured by Cronbach's $\alpha$, which was acceptable.

Table 6: Reliability for the cognitive load rating scale

\begin{tabular}{|l|c|}
\hline \multicolumn{1}{|c|}{ Aspect } & Cronbach's $\alpha$ \\
\hline Difficulty & 0.751 \\
\hline Incompetence & 0.733 \\
\hline Negative affect & 0.829 \\
\hline Lack of effort & 0.819 \\
\hline Overall & 0.814 \\
\hline
\end{tabular}




\section{Result and discussion}

\section{Data processing}

A total of 137 valid samples were collected. Among these 137 valid samples, 66 samples were in the single mode group and 71 samples were in the double mode group.

\section{Effect of media presentation mode on English listening comprehension and cognitive load (Research questions 1 and 2)}

\section{Test of homogeneity}

As shown in Table 7, Box's test of equality of covariance matrices $(F=5.327, p=.155)$ and Levene's test of equality of covariance (listening comprehension: $F=.348, p=.556$; cognitive load: $F=.041, p=.840$ ) were insignificant, meaning that the variance of listening comprehension and cognitive load was equal across groups and the homogeneity assumption was sustained. Furthermore, Wilk's $\lambda(F=0.985, p=.364)$ and regression slope (listening comprehension: $F=1.675, p=.198$; cognitive load: $F=$ $.048, p=.828)$ appeared insignificant, suggesting that the homogeneity assumption was sustained and the covariance (pretest) had the same degree of impact to the participants. Therefore, a two-way MANCOVA could be performed.

Table 7: Test of homogeneity for English listening comprehension and cognitive load

\begin{tabular}{|c|c|c|c|c|c|c|c|c|}
\hline \multirow{2}{*}{$\begin{array}{l}\text { Dependent } \\
\text { variable }\end{array}$} & \multicolumn{2}{|c|}{ Box's $M$} & \multicolumn{2}{|c|}{ Levene's test } & \multicolumn{2}{|c|}{ Wilk's $\lambda$} & \multicolumn{2}{|c|}{ Regression slope } \\
\hline & $\mathrm{F}$ & Sig. & $\mathrm{F}$ & Sig. & $\mathrm{F}$ & Sig. & $\mathrm{F}$ & Sig. \\
\hline $\begin{array}{l}\text { English listening } \\
\text { comprehension }\end{array}$ & 5.327 & 0.155 & 0.348 & 0.556 & 0.985 & 0.364 & 1.675 & 0.198 \\
\hline Cognitive load & & & 0.041 & 0.840 & & & 0.048 & 0.828 \\
\hline
\end{tabular}

Two-way multivariate analysis of covariance (MANCOVA)

As shown in Table 8, for English listening comprehension, learners in the double mode group outperformed learners in the single mode group. For cognitive load, learners receiving single mode encountered a higher level than learners receiving double mode. As shown in Table 9, Wilk's lambda showed a significant result, indicating that learners in both groups had significant differences in at least one dependent variable (English listening comprehension or cognitive load). The analysis of two-way MANCOVA, with covariance of English listening proficiency, showed that there was a significant difference in listening comprehension $(p<.05)$ between the two groups, indicating that learners in the double mode group outperformed learners in the single mode group.

There was a significant difference in cognitive load $(p<.05)$ between the two groups, revealing that the single mode group had higher cognitive load than the double mode group. Both groups had significant differences in listening comprehension and cognitive load, but the estimated effect size for listening comprehension $\left(\eta^{2}=0.117\right)$ was greater than cognitive load $\left(\eta^{2}=0.033\right)$. This implied that media presentation mode had more impact on listening comprehension than on cognitive load, and both groups had more differences in listening comprehension than in cognitive load. 
Table 8: Descriptive statistics for listening comprehension and cognitive load

\begin{tabular}{|l|c|c|c|c|}
\cline { 2 - 5 } \multicolumn{1}{|c|}{ Aspect } & \multicolumn{2}{c|}{ Single mode } & \multicolumn{2}{c|}{ Double mode } \\
\cline { 2 - 5 } & Mean & Std deviation & Mean & Std deviation \\
\hline English listening comprehension & 6.667 & 1.916 & 8.099 & 2.262 \\
\hline Cognitive load & 51.617 & 20.458 & 44.621 & 19.907 \\
\hline
\end{tabular}

Table 9: Two-way MANCOVA summary of listening comprehension and cognitive load

\begin{tabular}{|c|c|c|c|c|c|c|c|c|}
\hline $\begin{array}{l}\text { Wilk's } \\
\lambda \text { (sig.) }\end{array}$ & Source & Aspect & $\begin{array}{l}\text { Type III sum } \\
\text { of squares }\end{array}$ & df & $\begin{array}{l}\text { Mean } \\
\text { square }\end{array}$ & $F$ & Sig. & $\begin{array}{c}\text { eta- } \\
\text { squared }\end{array}$ \\
\hline \multirow{8}{*}{$\begin{array}{c}0.877 \\
(0.000)\end{array}$} & \multirow{2}{*}{$\begin{array}{l}\text { Covari- } \\
\text { ance }\end{array}$} & $\begin{array}{l}\text { Listening com- } \\
\text { prehension }\end{array}$ & 66.780 & 1 & 66.780 & $16.878^{*}$ & 0.000 & 0.112 \\
\hline & & Cognitive load & 6183.521 & 1 & 6183.521 & $16.993^{*}$ & 0.000 & 0.113 \\
\hline & \multirow{2}{*}{$\begin{array}{l}\text { Between } \\
\text { group }\end{array}$} & $\begin{array}{l}\text { Listening com- } \\
\text { prehension }\end{array}$ & 70.070 & 1 & 70.070 & $17.709^{*}$ & 0.000 & 0.117 \\
\hline & & Cognitive load & 1671.568 & 1 & 1671.568 & $4.594^{*}$ & 0.034 & 0.033 \\
\hline & \multirow{2}{*}{$\begin{array}{l}\text { Within } \\
\text { group }\end{array}$} & $\begin{array}{l}\text { Listening com- } \\
\text { prehension }\end{array}$ & 530.197 & 134 & 3.957 & & & \\
\hline & & Cognitive load & 48760.674 & 134 & 363.886 & & & \\
\hline & \multirow[t]{2}{*}{ Total } & $\begin{array}{l}\text { Listening com- } \\
\text { prehension }\end{array}$ & 8187.000 & 137 & & & & \\
\hline & & Cognitive load & 372151.143 & 137 & & & & \\
\hline
\end{tabular}

\section{Discussions}

In the ubiquitous learning environment, learners in the single mode group encountered higher extraneous cognitive load due to the lack of text support. On the other hand, learners in the double mode group had lower extraneous cognitive load because they received support from text. Some learners learning with double mode needed only to overcome intrinsic cognitive load from the material itself. Hence, learners learning with double mode outperformed learners learning with single mode. For the double mode, the modality effect occurred, but the redundancy effect did not. These results confirmed some findings on cognitive load (Diao, et al., 2007; Jones \& Plass, 2002). A study by Chung (2008) revealed that learners with high English proficiency had lower cognitive load when they learned with double mode. So, the result in the present study that learners who learned with double mode had lower cognitive load could be explained by their sufficient English proficiency. Based on the result of the present study, text enhanced students' listening comprehension and lowered their cognitive load. At the same time, the result also confirmed the viewpoint by Baddeley (2000) that information could be received from both visual and auditory channels for increasing the capacity of the working memory and helping students learn, which referred to the modality effect from the cognitive load theory (Sweller, 2005).

\section{The correlation between English listening comprehension and cognitive load (Research question 3)}

A Pearson correlation was performed in the present study to examine if there was a correlation between English listening comprehension and cognitive load. As shown in Table 10, English listening comprehension and cognitive load had a significant negative correlation $(r=-0.393 ; p<0.001)$ 
Table 10: Correlations between English listening comprehension and cognitive load

\begin{tabular}{|l|c|c|}
\hline \multicolumn{1}{|c|}{ Aspect } & $\begin{array}{c}\text { English listening } \\
\text { comprehension }\end{array}$ & $\begin{array}{c}\text { Cognitive } \\
\text { load }\end{array}$ \\
\hline English listening comprehension & 1.000 & \\
\hline Cognitive load & $-0.393^{* * *}$ & 1.000 \\
\hline${ }^{* * *} p<0.001$
\end{tabular}

In ubiquitous learning environment, learners who performed well in English listening comprehension encounterd lower cognitive load, and vice versa. This result supported the cognitive load theory and confirmed most findings on cognitive load (Chung, 2008; Diao et al., 2007; Diao \& Sweller, 2007; Jones \& Plass, 2002) that learners having low cognitive load performed well.

\section{Effect of media presentation mode on extended English listening comprehension and extended cognitive load (Research questions 4 and 5)}

Test of homogeneity

As shown in Table 11, Box's test of equality of covariance matrices $(F=.276, p=.965)$ and Levene's test of equality of covariance (extended listening comprehension: $F=$ $.691, p=.407$; extended cognitive load: $F=.067, p=.796)$ were insignificant, meaning that the variance of extended listening comprehension and extended cognitive load was equal across groups and the homogeneity assumption was sustained. Furthermore, Wilk's $\lambda(F=0.997, p=.847)$ and regression slope (extended listening comprehension: $F=.333, p=.565$; extended cognitive load: $F=.001, p=.974$ ) appeared insignificant, suggesting that the homogeneity assumption was sustained and the covariance (pretest) had the same degree of impact on the participants. Therefore, twoway MANCOVA could be performed.

Table 11: Test of homogeneity for extended English listening comprehension and extended cognitive load

\begin{tabular}{|c|c|c|c|c|c|c|c|c|}
\hline \multirow{2}{*}{$\begin{array}{l}\text { Dependent } \\
\text { variable }\end{array}$} & \multicolumn{2}{|c|}{ Box's $M$} & \multicolumn{2}{|c|}{$\begin{array}{l}\text { Levene's } \\
\text { test }\end{array}$} & \multicolumn{2}{|c|}{ Wilk's $\lambda$} & \multicolumn{2}{|c|}{$\begin{array}{l}\text { Regression } \\
\text { slope }\end{array}$} \\
\hline & $\mathrm{F}$ & Sig. & $\mathrm{F}$ & Sig. & $\mathrm{F}$ & Sig. & $\mathrm{F}$ & Sig. \\
\hline $\begin{array}{l}\text { Extended English } \\
\text { listening comprehension }\end{array}$ & 0.276 & 0.965 & 0.691 & 0.407 & 0.997 & 0.847 & 0.333 & 0.565 \\
\hline $\begin{array}{l}\text { Extended } \\
\text { cognitive load }\end{array}$ & & & 0.067 & 0.796 & & & 0.001 & 0.974 \\
\hline
\end{tabular}

Two-way multivariate analysis of covariance (MANCOVA)

As shown in Table 12, for extended English listening comprehension, learners in the double mode group slightly outperformed learners in the single mode group. For extended cognitive load, learners receiving single mode attained a higher level than learners receiving double mode. As shown in Table 13, Wilk's $\lambda$ showed an insignificant result, indicating that learners in both groups did not have a significant difference in both dependent variables (extended English listening comprehension and extended cognitive load). The analysis of two-way MANCOVA, with covariance of English listening proficiency, showed that there was no significant difference in extended listening comprehension $(p=.340)$ and extended cognitive load $(p=.497)$ between the two groups. 
Table 12: Descriptive statistics for extended listening comprehension and extended cognitive load

\begin{tabular}{|l|c|c|c|c|}
\hline \multirow{2}{*}{ Aspect } & \multicolumn{2}{c|}{ Single mode } & \multicolumn{2}{c|}{ Double mode } \\
\cline { 2 - 5 } & Mean & Std dev & Mean & Std dev \\
\hline Extended English listening comprehension & 2.02 & 1.196 & 2.20 & 1.179 \\
\hline Extended cognitive load & 48.426 & 19.480 & 46.224 & 19.122 \\
\hline
\end{tabular}

Table 13: Two-way MANCOVA summary on extended listening comprehension and extended cognitive load

\begin{tabular}{|c|c|c|c|c|c|c|c|c|}
\hline $\begin{array}{l}\text { Wilk's } \\
\lambda \text { (sig.) }\end{array}$ & Source & Aspect & $\begin{array}{l}\text { Type III } \\
\text { Sum of } \\
\text { squares }\end{array}$ & $\mathrm{df}$ & $\begin{array}{l}\text { Mean } \\
\text { square }\end{array}$ & $F$ & Sig. & $\begin{array}{c}\text { eta- } \\
\text { squared }\end{array}$ \\
\hline \multirow{8}{*}{$\begin{array}{c}0.991 \\
(0.545)\end{array}$} & \multirow{2}{*}{$\begin{array}{l}\text { Covar- } \\
\text { iance }\end{array}$} & $\begin{array}{l}\text { Extended listening } \\
\text { comprehension }\end{array}$ & 25.421 & 1 & 25.421 & $20.670^{*}$ & 0.000 & 0.134 \\
\hline & & $\begin{array}{l}\text { Extended cognitive } \\
\text { load }\end{array}$ & 2957.325 & 1 & 2957.325 & $8.377^{*}$ & 0.004 & 0.590 \\
\hline & \multirow{2}{*}{$\begin{array}{l}\text { Between } \\
\text { group }\end{array}$} & $\begin{array}{l}\text { Extended listening } \\
\text { comprehension }\end{array}$ & 1.128 & 1 & 1.128 & 0.918 & 0.340 & 0.007 \\
\hline & & $\begin{array}{l}\text { Extended cognitive } \\
\text { load }\end{array}$ & 163.680 & 1 & 163.680 & 0.464 & 0.497 & 0.003 \\
\hline & \multirow{2}{*}{$\begin{array}{l}\text { Within } \\
\text { group }\end{array}$} & $\begin{array}{l}\text { Extended listening } \\
\text { comprehension }\end{array}$ & 164.803 & 134 & 1.230 & & & \\
\hline & & $\begin{array}{l}\text { Extended cognitive } \\
\text { load }\end{array}$ & 47303.815 & 134 & 353.014 & & & \\
\hline & \multirow{2}{*}{ Total } & $\begin{array}{l}\text { Extended listening } \\
\text { comprehension }\end{array}$ & 801.000 & 137 & & & & \\
\hline & & $\begin{array}{l}\text { Extended cognitive } \\
\text { load }\end{array}$ & 356800.660 & 137 & & & & \\
\hline
\end{tabular}

\section{Discussion}

According to the results in the present study, learners receiving single mode had no significant difference with learners receiving double mode, in extended English listening comprehension and extended cognitive load. The reason for this was that learners learning with double mode during the ubiquitous learning were used to learning with the support of text, so when there was no support from text in the extended learning and test, learners would have higher extraneous cognitive load and lower listening comprehension scores. Thus, combining with the result of the last section, text caused the modality effect and lowered students' extraneous cognitive load temporarily. However, text did not efficiently assist students to store knowledge in long term memory. This result confirmed a study on an extended test by Diao et. al (2007). Another reason for explaining this result is that the extended learning happened seven days after the ubiquitous learning activity, which implied that students without immediate review would have difficulty in building up schema in long term memory. Therefore, instructors should provide review sessions to learners in listening training, in order to help them build up schema.

\section{The correlation between extended English listening comprehension and extended cognitive load (Research question 6)}

Pearson correlations were performed to examine whether there was a correlation between extended English listening comprehension and extended cognitive load. As 
shown in Table 14, extended English listening comprehension and extended cognitive load had a significant negative correlation $(r=-0.214 ; p<0.05)$.

Table 14: Correlations between English listening comprehension and cognitive load

\begin{tabular}{|l|c|c|}
\hline \multicolumn{1}{|c|}{ Aspect } & $\begin{array}{c}\text { Extended English } \\
\text { listening comprehension }\end{array}$ & $\begin{array}{c}\text { Extended } \\
\text { cognitive load }\end{array}$ \\
\hline Extended English listening comprehension & 1.000 & \\
\hline Extended cognitive load & -0.214 & 1.000 \\
\hline${ }^{*} p<0.05$ & \multicolumn{2}{|}{} \\
\hline
\end{tabular}

In the extended test, learners who performed well in English listening comprehension experienced lower cognitive load, and vice versa. This result was identical to the correlation between English listening comprehension and cognitive load.

\section{Discussion concerning all research questions}

Cognitive load and extended cognitive load

In the ubiquitous learning environment, learners learning with double mode outperformed in the English listening test and had significantly lower cognitive load than learners learning with single mode. Learners learning with single mode obtained slightly lower extended test scores and had higher extended cognitive load than learners learning with double mode, but the result was insignificant. Taking a closer look at the correlation between their cognitive load and extended cognitive load, as shown in Tables 15 and 16, although the correlation was not statistically significant, the level of cognitive load for learners who learned by single mode was tending lower from the ubiquitous learning to the extended learning, whereas the level of cognitive load for learners who learned by double mode was tending higher from the ubiquitous learning to the extended learning

Table 15: Paired $t$-test of cognitive load and extended cognitive load for single mode

\begin{tabular}{|l|c|c|c|c|c|}
\hline \multicolumn{1}{|c|}{ Aspect } & $\mathrm{N}$ & Mean & Std dev & $t$ & Sig. \\
\cline { 1 - 4 } Cognitive load & 66 & 51.617 & 20.458 & 1.409 & 0.164 \\
\cline { 1 - 4 } Extended cognitive load & 66 & 48.426 & 19.480 & & \\
\hline
\end{tabular}

Table 16: Paired $t$-test of cognitive load and extended cognitive load for double mode

\begin{tabular}{|l|c|c|c|c|c|}
\hline \multicolumn{1}{|c|}{ Aspect } & $\mathrm{N}$ & Mean & Std dev & $t$ & Sig. \\
\cline { 1 - 4 } Cognitive load & 71 & 44.621 & 19.907 & -0.731 & 0.467 \\
\cline { 1 - 4 } Extended cognitive load & 71 & 46.224 & 19.122 & & \\
\hline
\end{tabular}

\section{Discussion}

The above findings could be explained by the fact that learners receiving single mode during the ubiquitous learning or the extended learning were used to learning by sound-only presentation mode. Some students in the single mode group had already built up schema for English listening in their long term memory, so they had low extraneous cognitive load. On the other hand, for learners receiving double mode in the ubiquitous learning, they became uncomfortable during the extended learning due to the lack of text support. Since learners receiving double mode did not build up schema for English listening in long term memory, they required more time and space to process information in working memory, which led to higher extraneous cognitive load. Based on the results in the present study, text enhanced English listening 
comprehension and lowered extraneous cognitive load, but was unhelpful to schema construction in long term memory, which confirmed the findings of Diao et al. (2007).

\section{Conclusions and implications}

For English listening comprehension, regardless of English listening proficiency, learners learning with double mode significantly outperformed learners learning with single mode. For cognitive load, learners learning with double mode had significantly lower cognitive load than learners learning with single mode, implying that text did not make the cognitive load become higher. In other words, the lack of text support led to higher cognitive load and was not beneficial for English listening. This finding revealed that text can facilitate learners in listening comprehension and lower their cognitive load efficiently. For the double mode, the modality effect was caused, but redundancy effect was not, which confirmed the study results on cognitive load (Debuse, Hede \& Lawley, 2009; Diao et al., 2007; Jones \& Plass, 2002; Low \& Sweller, 2005; Moreno \& Mayer, 2002; Plass et al., 2003; Tabbers, Martens \& Van Merriënboer, 2004).

In both ubiquitous learning and extended learning, learners' English listening comprehension and cognitive load had a significantly negative correlation. This phenomenon is similar to the cognitive load theory that learners' cognitive load influences their learning performance. The finding confirmed the most related studies (Chung, 2008; Diao et al., 2007; Diao \& Sweller, 2007; Jones \& Plass, 2002).

Regarding the findings for research questions 1, 2, 4 and 5, in the ubiquitous learning environment, learners in the double mode group obtained higher grades on listening comprehension test and had lower cognitive load than learners in the single mode group. However, in the extended learning, there was no significant difference between groups in English listening comprehension and cognitive load. This finding implied that text could only temporarily enhance learners' English listening comprehension, lower learners' cognitive load and cause the modality effect, but could not efficiently help learners store knowledge in long term memory. This result was identical to the findings by Diao et al. (2007). Furthermore, extended cognitive load tended to be low for learners in the single mode group, but high for learners in the double mode group. This event revealed that learners who learned with double mode tended to have a hard time in accommodating themselves to the learning environment with single mode (auditory only). Therefore, text is not an efficient support for listening training.

According to the present study findings, text could temporarily enhance learning performance and lower cognitive load, but it could not efficiently help learners store knowledge in long term memory. This result showed that text is not essential to listening. Materials with an abundance of media presentations will not definitely enhance learning performance, so it is important to utilise media appropriately and take subject matter, learners' proficiency and learners' educational background into account. Providing students an appropriate media presentation mode for learning will reduce unnecessary cognitive load and efficiently help students build up schema.

Although text significantly enhances English listening comprehension, learning without reviews is more difficult for learners to build up schema in long term memory. So, instructors who teach English listening are encouraged to provide teaching materials with double mode (simultaneous sound and text) for facilitating learners' 
listening comprehension. After the listening class is over, instructors should provide review materials with single mode (sound only) for assisting students to build up schema.

English listening comprehension and cognitive load showed a significant negative correlation. Based on some relevant studies (Pawley et al., 2005; Paas et al., 2003), extraneous cognitive load can be lowered by appropriate instructional designs and learning activities. So, instructors should pay much attention to the impact of cognitive load because learners without unnecessary information in the working memory learn more efficiently.

The comparisons among single mode, double mode and triple mode, such as sound, text and image, with different learning environments, including traditional learning and multimedia digital learning, could be included in future studies. Also, the presentation modes of text can be further categorised into synchronisation and nonsynchronisation to examine the effect of text presentation mode on learning performance and cognitive load. For cognitive load, extraneous cognitive load can be lowered by instructional design choices, so it is appropriate to be a dependent variable in the experiment. Therefore, the present study focused only on examining the effect of two different presentation modes on extraneous cognitive load. Intrinsic cognitive load and germane cognitive load could be considered as the other dependent variables in future studies.

Learners' prior knowledge or proficiency would be an important factor for determining an appropriate media presentation mode for learners (Chung, 2008). English proficiency was a covariance in the present study. Prior knowledge or learners' characteristics, such as learning styles and media preference, could be other independent variables in a future study. Furthermore, the interaction between learners' prior knowledge and media presentation mode and its effects on learning performance and cognitive load with two-way ANOVA are suggested for future research.

The ubiquitous learning activity in the present study was held outdoors, so for some students, listening comprehension would be influenced negatively by the crowd, weather or other external factors. Researchers could include holding outdoor learning activities on campus in the future research. If researchers conduct the learning activity in a public place, selection of a quiet day may be best, to minimise unexpected interruptions.

\section{References}

Baddeley, A. D. (2000). The episodic buffer: A new component of working memory? Trends in Cognitive Science, 4(11), 417-423. http: / / dx.doi.org/10.1016/S1364-6613(00)01538-2

Chang, C. Y., Sheu, J. P. \& Chan, T. W. (2003). Concept and design of ad hoc and mobile classrooms. Journal of Computer Assisted Learning, 19(3), 336-346. http: / / dx.doi.org/10.1046/j.0266-4909.00035.x

Chen, C. M. \& Chung, C. J. (2008). Personalized mobile English vocabulary learning system based on item response theory and learning memory cycle. Computers $\mathcal{E}$ Education, 51(2), 624645. http:/ / dx.doi.org/10.1016/j.compedu.2007.06.011

Chiou, C. K., Tseng, C. R., Hwang, G. J. \& Heller, S. (2010). An adaptive navigation support system for conducting context-aware ubiquitous learning in museums. Computers $\mathcal{E}$ Education, 55(2), 834-845. http:/ / dx.doi.org/10.1016/j.compedu.2010.03.015 
Chung, K. K. H. (2008). What effect do mixed sensory mode instructional formats have on both novice and experienced learners of Chinese characters? Learning and Instruction, 18(1), 96-108. http: / / dx.doi.org/10.1016/j.learninstruc.2007.01.001

Debuse, J. C. W., Hede, A. \& Lawley, M. (2009). Learning efficacy of simultaneous audio and onscreen text in online lectures. Australasian Journal of Educational Technology, 25(5), 748-762. http: / / www.ascilite.org.au/ajet/ajet25/debuse.html

Diao, Y., Chandler, P. \& Sweller, J. (2007). The effect of written text on comprehension of spoken English as a foreign language. American Journal of Psychology, 120(2), 237-261. http: / / www.jstor.org/ stable/ 20445397

Diao, Y. \& Sweller, J. (2007). Redundancy in foreign language reading comprehension instruction: Concurrent written and spoken presentations. Learning and Instruction, 17(1), 7888. http: / / dx.doi.org/10.1016/j.learninstruc.2006.11.007

Jamet, E. \& Le Bohec, O. (2007). The effect of redundant text in multimedia instruction. Contemporary Educational Psychology, 32(4), 588-598. http: / / dx.doi.org/10.1016/j.cedpsych.2006.07.001

Jones, L. C. \& Plass, J. L. (2002). Supporting listening comprehension and vocabulary acquisition in French with multimedia annotations. The Modern Language Journal, 86(4), 546-561. http: / / www.jstor.org/ stable/1192724

Kalyuga, S., Chandler, P. \& Sweller, J. (2000). Incorporating learner experience into the design of multimedia instruction. Journal of Educational Psychology, 92(1), 126-136. http: / / psycnet.apa.org/doi/10.1037 / 0022-0663.92.1.126

Li, L., Zheng, Y., Ogata, H. \& Yano, Y. (2005). A conceptual framework of computer-supported ubiquitous learning environment. Journal of Advanced Technology for Learning, 2(4), 187-197. http: / / www.actapress.com / Abstract.aspx?paperId=19697

Liu, T. Y. \& Chu, Y. L. (2010). Using ubiquitous games in an English listening and speaking course: Impact on learning outcomes and motivation. Computers $\mathcal{E}$ Education, 55(2), 630-643. http: / / dx.doi.org/10.1016/j.compedu.2010.02.023

Low, R. \& Sweller, J. (2005). The modality principle in multimedia learning. In R.E. Mayer (Ed.), The Cambridge handbook of multimedia learning. Cambridge University Press, New York.

Markham, P. (1999). Captioned videotapes and second-language listening word recognition. Foreign Language Annals, 32(3), 321-328. http:/ / dx.doi.org/10.1111/j.1944-9720.1999.tb01344.x

Mayer, R. E., Heiser, J. \& Lonn, S. (2001). Cognitive constraints on multimedia learning: When presenting more material results in less understanding. Journal of Educational Psychology, 93(1), 187-198. http: / / psycnet.apa.org/doi/10.1037/0022-0663.93.1.187

Mayer, R. E. \& Moreno, R. (2003). Nine ways to reduce cognitive load in multimedia learning. Educational Psychologist, 38(1), 43-52. http:/ / dx.doi.org/10.1207/S15326985EP3801_6

Moreno, R. (2002). Who learns best with multiple representations? Cognitive theory predictions on individual differences in multimedia learning. In P. Barker \& S. Rebelsky (Eds.), Proceedings of World Conference on Educational Multimedia, Hypermedia and Telecommunications 2002 (pp.1380-1385). Chesapeake, VA: AACE Press.

Moreno, R. \& Mayer, R. E. (2002). Verbal redundancy in multimedia learning: When reading helps listening. Journal of Educational Psychology, 94(1), 156-163. http:/ / editlib.org/p/ 10238

Nash, S. S. (2007). Mobile learning, cognitive architecture and the study of literature. Issues in Informing Science and Information Technology, 4, 811-818. http: / / www.informingscience.org/ proceedings/ InSITE2007/ IISITv4p811-818Nash399.pdf 
Osada, N. (2004). Listening comprehension research: A brief review of the past thirty years. Dialogue, 3, 53-66. http:/ / www.talk-waseda.net/dialogue/no03_2004/2004dialogue03_k4.pdf

Paas, F. G. W. C., Renkl, A. \& Sweller, J. (2003). Cognitive load theory and instructional design: Recent developments. Educational Psychologist, 38(1), 1-4. http: / / dx.doi.org/10.1207/S15326985EP3801_1

Paas, F. G. W. C., Tuovinen, J. E., Tabbers, H. \& Van Gerven, P. W. M. (2003). Cognitive load measurement as a means to advance cognitive load theory. Educational Psychologist, 38(1), 6371. http:/ / dx.doi.org/10.1207/S15326985EP3801_8

Pawley, D., Ayres, P., Cooper, M. \& Sweller, J. (2005). Translating words into equations: A cognitive load theory approach. Educational Psychology, 25(1), 75-97. http: / / dx.doi.org/10.1080/0144341042000294903

Plass, J. L., Chun, D. M., Mayer, R. E. \& Leutner, D. (2003). Cognitive load in reading a foreign language text with multimedia aids and the influence of verbal and spatial abilities. Computers in Human Behavior, 19(2), 221-243. http:/ / dx.doi.org/10.1016/S07475632(02)00015-8

Sakar, A. \& Ercetin, G. (2005). Effectiveness of hypermedia annotations for foreign language reading. Journal of Computer Assisted Learning, 21(1), 28-38. http: / / dx.doi.org/10.1111/j.13652729.2005.00108.x

Sweller, J. (2005). Implications of cognitive load theory for multimedia learning. In R. E. Mayer (Ed.), The Cambridge handbook of multimedia learning (pp.19-29). New York, NY: Cambridge University Press.

Sweller, J. (2007). Keynote address: Cognitive load. Paper presented at the Symposium on Cognitive Load: Theory and Applications. Fo Guang University, Yilan, Taiwan.

Sweller, J., Van Merriënboer, J. J. G. \& Paas, F. G. W. C. (1998). Cognitive architecture and instructional design. Educational Psychology Review, 10(3), 251-297. http:/ / dx.doi.org/10.1023/A:1022193728205

Tabbers, H. K., Martens, R. L. \& Van Merriënboer, J. J. G. (2004). Multimedia instructions and cognitive load theory: Effects of modality and cueing. British Journal of Educational Psychology, 74(1), 71-81. http:/ / dx.doi.org/10.1348/000709904322848824

Tan, T. H., Liu, T. Y. \& Chang, C. C. (2007). Development and evaluation of an RFID-based ubiquitous learning. Interactive Learning Environments, 15(3), 253-269. http: / / dx.doi.org/10.1080/10494820701281431

Teng, H. C. (2006). A study of listening strategy instruction to EFL college students. Studies in English Language and Literature, 18, 29-39.

Yang, J. C. \& Lin, Y. L. (2010). Development and evaluation of an interactive mobile learning environment with shared display groupware. Educational Technology E Society, 13(1), 195-207. http: / / www.ifets.info/download_pdf.php?j_id=46\&a_id=1030

Yang, J. H. (2006). Context aware ubiquitous learning environments for peer-to-peer collaborative learning. Educational Technology \& Society, 9(1), 188-201.

http: / / www.ifets.info/download_pdf.php?j_id=30\&a_id=612

Yeung, A. S., Lee, C. F. K., Pena, I. M. \& Ryde, J. (2000). Toward a subjective mental workload measure. Paper presented at the International Congress for School Effectiveness and Improvement, Hong Kong, China. http:/ / www.eric.ed.gov:80/ERICWebPortal/ content delivery / servlet/ ERICServlet?accno=ED446117 
Appendix 1: Item analysis for the listening test

\begin{tabular}{|c|c|c|c|c|c|}
\hline Item & $\mathrm{CR}$ & $\begin{array}{c}\text { Item-total } \\
\text { correlation }\end{array}$ & Difficulty & Discrimination & Delete/Retain \\
\hline 1 & $5.186^{* * *}$ & $0.415^{\star *}$ & 0.662 & 0.465 & Retain \\
\hline 2 & $4.317^{* * *}$ & $0.331^{* *}$ & 0.811 & 0.336 & Retain \\
\hline 3 & $3.784^{* * *}$ & $0.309^{* *}$ & 0.194 & 0.292 & Retain \\
\hline 4 & $2.956^{* *}$ & $0.356^{* *}$ & 0.509 & 0.303 & Retain \\
\hline 5 & $4.241^{* * *}$ & $0.344^{* *}$ & 0.517 & 0.413 & Retain \\
\hline 6 & $3.186^{* *}$ & $0.293^{* *}$ & 0.779 & 0.272 & Retain \\
\hline 7 & 1.538 & $0.173^{*}$ & 0.389 & 0.158 & Delete \\
\hline 8 & $2.582^{*}$ & $0.195^{*}$ & 0.442 & 0.264 & Retain \\
\hline 9 & 0.196 & 0.114 & 0.416 & 0.021 & Delete \\
\hline 10 & 1.969 & $0.241^{* *}$ & 0.579 & 0.205 & Delete \\
\hline 11 & $3.654^{* * *}$ & $0.321^{* *}$ & 0.586 & 0.361 & Retain \\
\hline 12 & $2.934^{* *}$ & $0.275^{* *}$ & 0.218 & 0.245 & Retain \\
\hline 13 & 1.693 & $0.182^{*}$ & 0.243 & 0.152 & Delete \\
\hline 14 & $5.646^{* * *}$ & $0.463^{* *}$ & 0.694 & 0.384 & Retain \\
\hline 15 & $3.549^{* *}$ & $0.287^{* *}$ & 0.306 & 0.325 & Retain \\
\hline 16 & $2.802^{* *}$ & $0.241^{* *}$ & 0.746 & 0.253 & Detain \\
\hline 17 & 1.755 & $0.181^{*}$ & 0.299 & 0.169 & Retain \\
\hline 18 & $4.779^{* * *}$ & $0.374^{* *}$ & 0.414 & 0.448 & Delete \\
\hline 19 & 1.178 & 0.133 & 0.244 & 0.108 & Retain \\
\hline 20 & $2.116^{*}$ & $0.228^{* *}$ & 0.443 & 0.220 & 0.327 \\
\hline Average & & & 0.523 & & \\
\hline
\end{tabular}

${ }^{*} p<0.05,{ }^{* *} p<0.01,{ }^{* * *} p<0.001$

\section{Appendix 2: Item analysis for the extended listening test}

\begin{tabular}{|c|c|c|c|c|c|}
\hline Item & $\mathrm{CR}$ & $\begin{array}{c}\text { Item-total } \\
\text { correlation }\end{array}$ & Difficulty & Discrimination & Delete/Retain \\
\hline 1 & $3.545^{* *}$ & $0.349^{* *}$ & 0.478 & 0.351 & Retain \\
\hline 2 & $5.894^{* * *}$ & $0.535^{* *}$ & 0.246 & 0.446 & Retain \\
\hline 3 & $7.150^{* * *}$ & $0.522^{* *}$ & 0.383 & 0.580 & Retain \\
\hline 4 & $7.150^{* * *}$ & $0.498^{* *}$ & 0.383 & 0.580 & Retain \\
\hline 5 & $8.021^{* * *}$ & $0.542^{* *}$ & 0.599 & 0.639 & Retain \\
\hline Average & & 0.418 & 0.519 & \\
\hline
\end{tabular}

${ }^{*} p<0.05,{ }^{* *} p<0.01,{ }^{* * *} p<0.001$

\section{Appendix 3: Item analysis for cognitive load rating scale}

\begin{tabular}{|c|c|c|c|}
\hline Item & CR & Item-total correlation & Delete/ Retain \\
\hline 1 & $-2.986^{* *}$ & $-0.371^{* *}$ & Retain \\
\hline 2 & $4.914^{* * *}$ & $0.477^{* *}$ & Retain \\
\hline 3 & $-3.719^{* * *}$ & $-0.370^{* *}$ & Retain \\
\hline 4 & $6.944^{* * *}$ & $0.494^{* *}$ & Retain \\
\hline 5 & $7.924^{* * *}$ & $0.548^{* *}$ & Retain \\
\hline 6 & $-2.710^{* *}$ & $-0.304^{* *}$ & Retain \\
\hline 7 & $5.634^{* * *}$ & $0.454^{* *}$ & Retain \\
\hline 8 & $-4.887^{* * *}$ & $-0.407^{* *}$ & Retain \\
\hline 9 & $4.617^{* * *}$ & $0.293^{* *}$ & Retain \\
\hline 10 & $-2.970^{* *}$ & $-0.354^{* *}$ & Retain \\
\hline 11 & $-2.826^{* *}$ & $-0.267^{* *}$ & Retain \\
\hline 12 & $8.680^{* * *}$ & $0.551^{* *}$ & Retain \\
\hline 13 & $-5.413^{* * *}$ & $-0.483^{* *}$ & Retain \\
\hline
\end{tabular}




\begin{tabular}{|c|c|c|c|}
\hline 14 & $-2.404^{*}$ & $-0.323^{* *}$ & Retain \\
\hline 15 & $7.559^{* * *}$ & $0.584^{* *}$ & Retain \\
\hline 16 & $3.000^{* *}$ & $0.291^{* *}$ & Retain \\
\hline \multicolumn{2}{|l}{${ }^{*} p<0.05,{ }^{* *} p<0.01,{ }^{* * *} p<0.001$} &
\end{tabular}

\section{Appendix 4: Factor analysis for cognitive load rating scale}

\begin{tabular}{|c|c|c|c|c|c|c|}
\hline Aspect & $\begin{array}{l}\text { Original } \\
\text { item }\end{array}$ & $\begin{array}{l}\text { Current } \\
\text { item }\end{array}$ & Eigenvalue & $\begin{array}{l}\text { Total \% of variance } \\
\text { cumulative }\end{array}$ & $\begin{array}{l}\text { Factor } \\
\text { loading }\end{array}$ & $\begin{array}{c}\text { Validity } \\
\text { coefficient }\end{array}$ \\
\hline \multirow[t]{4}{*}{ Difficulty } & 1 & 15 & \multirow[t]{4}{*}{2.294} & \multirow[t]{4}{*}{$57.343 \%$} & 0.760 & 0.597 \\
\hline & 2 & 2 & & & 0.764 & 0.551 \\
\hline & 3 & 5 & & & 0.618 & 0.671 \\
\hline & 4 & 12 & & & 0.629 & 0.616 \\
\hline \multirow[t]{4}{*}{ Incompetence } & 5 & 4 & \multirow[t]{4}{*}{2.247} & \multirow[t]{4}{*}{$56.175 \%$} & 0.834 & 0.722 \\
\hline & 6 & 7 & & & 0.780 & 0.776 \\
\hline & 7 & 9 & & & 0.492 & 0.567 \\
\hline & 8 & 16 & & & 0.824 & 0.699 \\
\hline \multirow[t]{4}{*}{ Negative affect } & 9 & 3 & \multirow[t]{4}{*}{2.683} & \multirow[t]{4}{*}{$67.066 \%$} & 0.810 & 0.684 \\
\hline & 10 & 1 & & & 0.793 & 0.672 \\
\hline & 11 & 10 & & & 0.800 & 0.657 \\
\hline & 12 & 6 & & & 0.796 & 0.663 \\
\hline \multirow[t]{4}{*}{ Lack of effort } & 13 & 11 & \multirow[t]{4}{*}{2.602} & \multirow[t]{4}{*}{$65.040 \%$} & 0.804 & 0.703 \\
\hline & 14 & 13 & & & 0.826 & 0.763 \\
\hline & 15 & 14 & & & 0.648 & 0.519 \\
\hline & 16 & 8 & & & 0.792 & 0.670 \\
\hline Overall & & & 3.741 & $65.813 \%$ & & \\
\hline
\end{tabular}

Authors: Dr Chi-Cheng Chang, Professor and Chairman, Department of Technology Application and Human Resource Development, National Taiwan Normal University, Taiwan. Email: samchang@ntnu.edu.tw

Mr Hao Lei, Department of Technology Application and Human Resource Development, National Taiwan Normal University, Taiwan.

Email: dghd77@gmail.com

Ms Ju-Shih Tseng (corresponding author), Department of Technology Application and Human Resource Development, National Taiwan Normal University, Taiwan.

Email: jstseng@ntnu.edu.tw

Please cite as: Chang, C.-C., Lei, H. \& Tseng, J.-S. (2011). Media presentation mode, English listening comprehension and cognitive load in ubiquitous learning environments: Modality effect or redundancy effect? Australasian Journal of Educational Technology, 27(4), 633-654. http:/ / www.ascilite.org.au/ajet/ajet27/ chang.html 